\title{
The Relationship between Multimodal Literacy of Pre-Service Teachers and Their Perception of Self-Efficacy in Critical Reading*
}

\author{
Hacer Ulu ${ }^{1}$, Ayşegül Avşar-Tuncay², Özlem Baş² \\ ${ }^{1}$ Bozhüyük Primary Afyonkarahisar Provincial Directorate of National Education, Afyonkarahisar, Turkey \\ ${ }^{2}$ Elementary Education Department, Hacettepe University, Ankara, Turkey \\ Correspondence: Hacer Ulu, Bozhüyük Primary Afyonkarahisar Provincial Directorate of National Education, \\ Afyonkarahisar, Turkey.
}

Received: September 18, 2017

Accepted: November 15, $2017 \quad$ Online Published: November 21, 2017

doi:10.11114/jets.v5i12.2806

URL: https://doi.org/10.11114/jets.v5i12.2806

\begin{abstract}
The aim of this study is to investigate the relationship between the multimodal literacy of pre-service teachers and their perception of self-efficacy in critical reading. At the same time, it is to what extent their multimodal literacy levels predict their perception of self-efficacy in critical reading. 337 students were chosen via convenience sampling for this study which was designed on the basis of relational survey model. The data which is needed to answer the relevant questions in our study was collected by means of Multimodal Literacy Scale (Bulut, Ulu and Kan, 2015) and Critical Reading Self-Sufficiency Perception Scale (Karadeniz, 2014). The analyses of the data collected were conducted through Pearson product-moment correlation coefficient analysis technique and multiple regression analysis technique. In view of the results we have obtained in this study, multimodalness is a strong predictive of self-efficacy perception in critical reading $(\mathrm{R}=.517 ; \mathrm{R} 2=.267)[\mathrm{F}(3.336)=40.483, \mathrm{p}<.000)$. The dimension of expressing oneself using multimodal structures $(\mathrm{r}=.362)$, interpretation of the contents presented in multimodal structures $(\mathrm{r}=.466)$ and preferring multimodal structures ( $\mathrm{r}=.209)$ has a positive and significant effect on critical reading self-efficacy perception.
\end{abstract}

Keywords: multimodalness, critical reading, self-efficacy

\section{Introduction}

Technological advances have resulted in certain changes in the field of education as well as having an impact on our social lives. They have made it a necessity to acquire the skills of obtaining and sharing information on digital media by taking the concept of literacy beyond reading and writing printed materials. Jewitt (2008) states that technology is instrumental in shaping the information within the curricula. Now it has become a necessity to redefine the term of literacy with the increasing importance of the visuals in those texts which students encounter (Kenner and Kress, 2003). With this in mind, the word "new" has been added to the term "literacy". Pendleton (2013) notes that new literacy requires students to use digital technology, to complete tasks by using online resources, to create multimodal products and to create meaning by using various elements. Because of this, terms such as "hypertext" or "multimodal text" have found their way into literature rather than printed texts.

How individuals elucidate meanings from the texts in digital technology environment and how they express themselves in this way have now become one of the current research subjects. Therefore, Walsh (2009) states that reading theories are still studying the interaction between the visual, auditory, spatial and textual modes separately and as a whole in digital texts and also Unsworth \& Chan (2009) state that the importance of speaking, listening and visual information which are not based on written information has begun to be debated as a result of digital advances. Various researchers have put forward a number of suggestions for the questions in this study. For instance, Liu (2013) notes that texts should be analysed in a multimode manner, paying attention to order, typography, colour, type, context, style etc. Loerts (2013) states that using the representations of some forms in the process of reading, writing, listening, speaking and expressing point of view and opinion is an important element in the process of sharing information, interacting with others and elucidating meaning. Kress (2005) underlines the importance of interpreting multimodal elements in texts to

\footnotetext{
${ }^{*}$ The summary of this paper was presented at the $1^{\text {st }}$ International Symposium on Social Sciences and Education Research in Antalya, 3-5 November, 2017.
} 
understand language, stating that literacy is a sophisticated process which involves building our prior knowledge, culture and experiences to elucidate deeper meanings (Quot. Pendleton, 2013). Besides theoretical views, a great number of researchers also have practical views with regard to enabling people to have multimodal literacy skills. Teachers should transform traditional literacy into multimodal-based education by using texts presented in various ways (books, cartoons, web sites, video games etc.) (Sewell \& Denton, 2011). Tüzel (2013) defines multimodal text as "the text in which written and oral elements as well as stationary and moving images are used together". Screen-based text types in which different elements are used (sound, visuals, writing, movement, animation etc.) have today become more common than paper-based texts. According to Zammit (2007), when a reader or writer is interacting with such a text, s/he should perceive all these elements as complimentary to each other, deriving a common meaning rather than trying to elucidate separate meanings for each of the elements. This demonstrates that the reader or writer has a more questioning and critical standing when s/he is building or producing meaning (Quot. Liu, 2013). Multimodal literacy is based on creating deeper meanings by using such skills as questioning, analysing and synthesizing the messages involving different elements (writing, visuals, sound etc.).

Today people are in an intensive interaction with technological devices such as televisions, computers, mobile phones etc. Structuring information in one's mind and expressing one's opinions after questioning the contents presented on such devices in a critical manner is one of the higher level skills. Therefore, it has now become impossible to regard multimodal literacy which is based on digital media and such skills as critical thinking and critical reading as separate concepts. Similarly, Smith (2014) states that many students acquire important knowledge and experience for critical thinking with the help of video games, while Walsh (2009) supports that digital reading strategies require developing inferential, analytical, critical and evaluative insights. Lankshear \& McLaren (1993) also state that critical literacy is central to the tradition and discipline built by multimodal literacy. People can create new things by trying different digital, visual, auditory devices and methods or by questioning to perform and tell about things which are imagined or discovered. Multimodal literacy is suitable for creating a critical outlook when it is investigated by choosing relevant materials and when it is designed within the framework of creative beliefs (Sanders \& Albers, 2010). Walsh (2010) states that students perform critical thinking and evaluation in most of the activities that involve digital technology. Students evaluate resources critically to choose relevant information and discuss others' studies. The aim is to devise a systematic approach in multimodal text analysis to improve analytical and critical thinking.

Critical reading is a type of reading which is based on acquiring high-level information rather than basic information. Gregori-Signes (2014) explains that critical reading emerges as a result of the need to comprehend contradictory elements and to evaluate information. To think critically during the process of reading, writing, listening and speaking, one has to share information in various and rich forms, interact with them and create meaning (Literacy For Learning, 2004; Quot. Rowsell \& Walsh, 2011; Smith, 2014). Özensoy (2011:13) defines critical reading as "an individual's judging, questioning and elucidating what s/he reads". According to Yıldız (2008: 135), if a reader adopts the habit of asking questions about a text, it means that s/he reflects on the content and arrives at his/her own truth by evaluating the subject in an impartial manner, taking both its positive and negative aspects into consideration. Meaning is elucidated within the framework of critical or socio-cultural analysis after the visual and textual elements are perceived and evaluated from some interpretive perspectives (Serafini, 2010). Today it has become a must to acquire critical reading skills in line with multimodal literacy.

Education plans should be devised to equip individuals with critical reading skills with a view to acquiring multimodal literacy skills, but researchers state that this is not such an easy task. Unsworth and Chan (2009) note that the level of difficulty in appreciating the various image/language relationships in printed copies and online texts vary from one student to another and these relationships is one of the most formidable issues.

Noting that relationships between distinct elements in multimodal texts is the central problem, Jewitt (2008) explains that these kinds of texts should be investigated by taking their production, meanings they produce, their interpretations and their prominent features into account. Quality education to develop and improve multimodal literacy will inevitably have an impact on the students' critical reading skills. Indeed, experimental studies carried out so far have proven that multimodal literacy improves critical reading skills with regard to creating meaning and expressing oneself.

Multimodal texts, which have emerged with the developing technology and changing living conditions, need to be handled in class environment. Therefore, teachers of mother tongue should be trained in a way that will enable them to train students by using multimodal texts. On the other hand, we see that critical reading skills are also required as a result of constructivist approach. In order for teachers to provide students with such skills, they need to have a sufficient level of knowledge about critical reading and their perception of self-efficacy in critical reading should be positive. For this reason, it is important that pre-service teachers acquire self-efficacy in multimodal literacy and critical reading during their undergraduate education. One of the mainstays of perception of self-efficacy in critical reading is multimodal literacy. This study is of importance in that it leads to propose that multimodal literacy could be a means of 
improving pre-service teachers' perception of self-efficacy in critical reading. During the process, we have encountered studies in international literature investigating how accurately multimodal literacy can predict perception of self-efficacy in critical reading. From this respect, we expect that this study will serve as a pioneer for the studies to be conducted in the future. This study shows that multimodal literacy can theoretically improve the perception of self-efficacy in critical reading in a positive manner. However, whether this supposed positive change is significant or not is expected to be demonstrated with the help of this study. The identification of this relationship bears importance in that it will shed light on literacy classes and education programs to be devised.

\subsection{Aim of the Research}

The aim of this study is to investigate the relationship between the multimodal literacy of pre-service teachers and their perception of self-efficacy in critical reading. At the same time, it is to what extent their multimodal literacy levels predict their perception of self-efficacy in critical reading.

\subsection{Research Questions}

We sought answers to the following questions to attain our aim:

- What is the level of multimodal literacy of pre-service teachers and their level of self-efficacy perception in critical reading?

- Is there a significant relationship between the sub-dimensions of multimodal literacy of pre-service teachers and their perception of self-efficacy in critical reading?

- Does the level of multimodal literacy of the pre-service teachers predict their perception of self-efficacy in critical reading?

\section{Method}

This study was designed according to relational survey model. Relational survey model is a research model which seeks to identify the presence or the degree of co-variance between two or more variables (Karasar, 1999:81). Pre-service teachers' perception of self-efficacy in critical reading has been determined as dependent variable in this study. Students' levels of multimodal literacy, on the other hand, have been determined as independent variable.

\subsection{Participant Characteristics}

The study population consists of total $3372^{\text {nd }}$ and $3^{\text {th }}$ grade pre-service teachers attending Hacettepe University, Education Faculty during the 2017-2018 academic year. The study sample included 337 teacher candidates in total, 110 of whom were from the preschool education department, 101 of whom were from the classroom education department, 126 of whom were from the science and technology education department. 284 of these pre-service teachers are female, while 53 are male. When identifying the study group, we used convenient sampling method. Convenient sampling method allows the study to be conducted faster and in a more practical way because researcher chooses circumstances which are near and thus within easy reach in this method (Yıldırım \& Şimşek, 2000).

\subsection{Data Collection Tools}

We have used two data collection instruments in this study. Multimodal literacy scale has been devised by Bulut, Ulu \& Kan (2015). After the exploratory factor analysis, the researchers have concluded that the scale is comprised of thee sub-dimensions (expressing oneself by using multimodal structures, interpretation of the contents presented in multimodal structures and preferring multimodal structures). The variance of this three-factor scale has been identified as $52.63 \%$ and its Cronbach Alpha coefficient is .875. According to confirmatory factor analysis (CFA) to determine the validity of the scale, the fit indices of the model of the scale devised as a three-factor structure are sufficient $\left(\chi^{2} / \mathrm{d} f=1.51\right.$, RMSEA $=.036, \mathrm{GFI}=.95, \mathrm{AGFI}=0.93$ ).

Critical reading self-efficacy scale has been devised by Karadeniz (2014). The researcher demonstrated that the scale is comprised of five sub-dimensions (questioning, deducing, analysis, evaluation and finding similarities/differences) with the exploratory factor analysis he has conducted. The variance of the five-factor scale was calculated as $53.85 \%$ and its Cronbach Alpha coefficient is .937. According to confirmatory factor analysis (CFA) to determine the validity of the scale, the fit indices of the model of the scale devised as a five-factor structure are sufficient.

\subsection{Data Analysis}

The relationship between the self-efficacy perceptions of the students in critical reading and the sub-dimensions of multimodal literacy has been investigated through multiple regression analysis. Multiple regression analysis focuses on independent variable which has a significant effect on the dependent variable. Independent variables that do not contribute significantly to the variance in dependent variable are excluded from the regression model (Büyüköztürk, 2002). Before the analysis is conducted, the researcher has to find out whether there are any outliers (extreme values) 
which are outside the plus and minus \pm 3 standard deviation by examining residual values. Therefore, regression analysis includes the assumptions which are named as "linearity" and "multivariate normality" in short. In addition, the graphic showing the relationship between standardized deviation values and standardized dependent variables was drawn and it was found out that the graphic does not have a specific pattern, so it was understood that the analysis is in conformity with the linearity assumption. "Normal P-P" graphic of observed and expected cumulative probability drawn to see the standardized deviation values has shown that there is not a significant deviation from normal distribution.

\section{Results}

We have calculated the mean values and standard deviation values of the answers given by the participants to the scales we used to identify the perception of self-efficacy perception in critical reading and levels of multimodal literacy sub-dimensions. The results obtained are given in Table 1.

Table 1. Pre-service teachers' levels of self-efficacy perception in critical reading and multimodal literacy sub-dimensions

\begin{tabular}{lcr}
\hline Variables & $\bar{X}$ & \multicolumn{1}{c}{ SS } \\
\hline Self-efficacy perception in critical reading & 3.89 & .77 \\
Expressing oneself using multimodal structure & 4.17 & .92 \\
Interpretation of the contents presented in multimodal structure & 4.13 & 1.12 \\
Preferring multimodal structures & 3.90 & 1.14 \\
\hline
\end{tabular}

As shown in Table 1, when we look at pre-service teachers' perception of self-efficacy in critical reading and their scores in the sub-dimensions of expressing oneself using multimodal literacy, interpretation of the contents presented in multimodal literacy and preferring multimodal structure, we can see that the highest score is in expressing oneself using multimodal structure $(X=4.17)$, followed by interpretation of the contents presented in multimodal structure ( $\mathrm{X}$ $=4.13)$, preferring multimodal structures $(\bar{X}=20.57)$ and self-efficacy perception in critical reading $(\bar{X}=3.89)$. According to the standard deviation values of multimodal literacy, the most homogenous evaluation is in expressing oneself using multimodal structure ( $\mathrm{SS}=.92)$, while the most heterogeneous evaluation is in preferring multimodal structures $(\mathrm{SS}=1.14)$.

Multiple regression analysis has been performed to see whether pre-service teachers' perception of self-efficacy in critical reading predicts the sub-dimensions of multimodal literacy and the results of this analysis have been given in Table 2 .

Table 2. Multiple regression analysis results showing the predictive power of multimodal literacy sub-dimensions of pre-service teachers as to their perception of self-efficacy in critical reading

\begin{tabular}{|c|c|c|c|c|c|c|c|}
\hline Variables & B & $\begin{array}{l}\text { Standard } \\
\text { Error }_{B}\end{array}$ & $\beta$ & $\mathrm{t}$ & $\mathrm{p}$ & $\begin{array}{c}\text { Pair } \\
\text { Correlation }\end{array}$ & $\begin{array}{c}\text { Partial } \\
\text { Correlation }\end{array}$ \\
\hline Constant & 73.382 & 5.523 & - & 13.287 & .000 & & \\
\hline $\begin{array}{l}\text { Expressing oneself using multimodal } \\
\text { structure }\end{array}$ & .516 & .233 & .124 & 2.214 & .027 & .362 & .120 \\
\hline $\begin{array}{l}\text { Interpretation of the contents } \\
\text { presented in multimodal structure }\end{array}$ & 1.226 & .171 & .397 & .397 & .000 & .466 & .366 \\
\hline Prreferrring multimodal structures & .623 & .167 & .179 & .179 & .000 & .209 & .201 \\
\hline
\end{tabular}

$\mathrm{R}=.517 \quad \mathrm{R}^{2}=.267$

$\mathrm{F}_{(3.336)=} 40.483 \quad \mathrm{p}=.000$

When we examine the pair correlation and partial correlation between the predictive variables and dependent variable, we see that there is positive and mid-level correlation between expressing oneself using multimodal structures and self-efficacy perception in critical reading $(\mathrm{r}=.362)$, but when we check the other variables, the correlation between two variables is $r=.120$. We see that there is positive and mid-level correlation between the dimension of interpretation of the contents presented in multimodal structures and self-efficacy perception in critical reading $(\mathrm{r}=.466)$, but when we check the other variables, the correlation between two variables has been calculated as $r=.366$. There is a positive and low-level correlation between the dimension of preferring multimodal structures and self-efficacy perception in critical reading $(\mathrm{r}=.209)$, but when the other variables are checked, the correlation between the two variables has been calculated as $\mathrm{r}=.201$.

There is a significant correlation between all the three sub-dimensions, namely expressing oneself using multimodal 
structures, interpretation of the contents presented in multimodal structures, preferring multimodal structures combined and participants' self-efficacy perception in critical reading. $\mathrm{R}=.517, \mathrm{R}^{2}=.267, \mathrm{p}<.01$. The three variables together can explain $26 \%$ of the total variance in perception of self-efficacy in critical reading.

According to the standardized regression coefficients $(\beta)$, the relative significance of predictive variables with regard to perception of self-efficacy in critical reading is interpretation of the contents presented in multimodal structures, preferring multimodal structures and expressing oneself using multimodal structures in descending order. When we examine the t-test results conducted to identify the significance of regression coefficients, we can see that the variables of interpretation of the contents presented in multimodal structures and preferring multimodal structures have significant predictive value with regard to perception of self-efficacy in critical reading. The other variable does not have a significant effect.

\section{Discussion}

In this study, the effects of the sub-dimensions of multimodal literacy on the perception of self-efficacy in critical reading have been investigated with the help of regression analysis. Given the results, we see that there is a positive and mid-level correlation between the sub-dimension of expressing oneself using multimodal structure and the perception of self-efficacy in critical reading. We have not encountered any studies in literature investigating the effects of the dimension of expressing oneself using multimodal structures on the perception of self-efficacy in critical reading through quantitative methods. Therefore, we cannot relate the findings of this study with other studies carried out before, but we have obtained findings both in theoretical terms and in experimental studies conducted showing that the dimension of expressing oneself using multimodal structures has an impact on the perception of self-efficacy in critical reading. In the study conducted by Pendleton (2013), students prepared weather reports by using various elements (visual, written etc.) after performing their research on the internet. The students designed their presentations by critically evaluating the contents on different websites as a part of their projects. The study conducted by Gregori-Signes (2014) shows that the digital stories that the students created on various subjects improve their critical reading skills. Interpreting information from a critical point of view increases the awareness of the students towards social reality. In the study he conducted, Turner (2011) enabled students to improve their literacy analysis skills by having them compose their own songs and ensured reliability in literacy skills (Quot. Smith, 2014). In the study carried out by Jewitt (2003), that students evaluating and integrating the meanings of the elements they used to refer to the action of "jumping" (motionless image, gesture, posture, speaking, animation, writing etc.) in a critical way showed that they were able to perform multimodal analysis. Parallel to this, according to Walsh (2009), when we are building multimodal structures, we can create products by evaluating the texts in a critical manner based on our objectives and impressions. Today a lot of people express themselves on social media such as facebook, twitter and youtube by producing games, videos, digital stories, texts etc. through various elements (picture, writing, animation, sound etc) on digital environments. They assess whether these products serve their purpose or not by critically evaluating these elements during production and sharing process.

Another finding is that there is a positive and mid-level correlation between the dimension of interpreting contents presented in multimodal structure and the perception of self-efficacy in critical reading. We have not found any study in literature investigating the effect of interpretation of the contents presented in multimodal structures on the perception of self-efficacy in critical reading through quantitative methods. Therefore, we couldn't compare our findings with other previous studies, but both theoretically and through experimental studies, we have obtained findings proving that the dimension of interpretation of the contents presented in multimodal structures have an effect on the perception of self-efficacy in critical reading. The study conducted by Jewitt (2008) showed that students make interpretations about the social and cultural contexts of meaning after the education they receive with regard to the analysis of how images and words are organised. Sewell and Denton (2011) conducted a study in which students did some critical thinking exercises allowing them to propose or reject the suitability of the projects presented in digital media to the objectives. The study conducted by Krause (2015) showed that most of the participants used more than one mode and multimedia device to widen their horizons with regard to their literacy experiences as well as demonstrating that it can meet the need for promoting critical thinking as a source of power through multimodal devices. Reading and evaluating the texts including multimodal elements improve critical reading skills. According to Serafini (2010), education should be offered with a view to synthesizing perceptive skills with regard to political, historical and cultural understanding by means of various interpretation strategies by stressing different aspects of interpreting texts. Students perform critical reading by choosing relevant information on the texts based on their interests and intuitions and explaining the reason why they have chosen that particular information (Heberle, 2010). One of the other findings is that there is a positive and low-level correlation between the dimension of preferring multimodal structure and the perception of self-efficacy in critical reading. Because there is not any study in field literature investigating this aspect of the subject, our finding s couldn't be compared to any other previous study. 


\section{Conclusion}

Some advice could be offered to practitioners, researchers and education programs with the help of the results we have obtained during this study. Students could prepare products on digital media by using various elements such as visuals, writing, animation etc. Teachers could help to enable them to interpret contents presented on digital media. Students' critical reading skills should improve through evaluating and relating the meanings represented by various elements. Likewise, Albers \& Harste (2007) state that problem solving skills of individuals improve when they design products containing images, expressions and visuals (Quot. Krause, 2015). Researchers could have suggestions as to how multimodal literacy and critical reading skills can be integrated into education programs and how they can be related with literacy theories. Similarly, Sanders \& Albers (2010) explain that researchers should assume responsibility of clarifying the nature and ideologies of multimodalness and criticism as they do in the case of creativity and coming up with suggestions as regards text design. Moreover, other studies that investigate the effects of multimodal literacy on critical reading skills or perception of self-efficacy could be conducted. Also, education programs could have suggestions to explain, in a systematic manner, how various kinds of studies dealing with the nature of multimodalness interact with the language in printed copies of different types and online texts.

\section{References}

Bulut, B., Ulu, H., \& Kan, A. (2015). Multimodal literacy scale: A study of validity and reliability. Eurasian Journal of Educational Research, 61, 45-60. https://doi.org/10.14689/ejer.2015.61.3

Büyüköztürk, Ş. (2002). Sosyal bilimler için veri analizi el kitabı: İstatistik, araştırma deseni SPSS uygulamaları ve yorum. Ankara: PegemA.

Gregori-Signes, C. (2014). Digital storytelling and multimodal literacy in education. Porta Linguarum, 22, 237-250.

Hassett, D. D., \& Curwood, J. S. (2009). Theories and practices of multimodal education: The instructional dynamics of picture books and primary classrooms. The Reading Teacher, 63(4), 270-282. https://doi.org/10.1598/RT.63.4.2

Heberle, V. (2010). Multimodal literacy for teenage EFL students. Cadernos de Letras, 27, 101-116.

Jewitt, C. (2003). A multimodal framework for computer mediated learning: the reshaping of curriculum knowledge and learning (Doctoral Dissertation). Institute of Education University of London, London.

Jewitt, C. (2008). Multimodality and literacy in school classrooms. Review of Research in Education, 32(1), 241-267. https://doi.org/10.3102/0091732X07310586

Karadeniz, A. (2014). Eleştirel okuma özyeterlilik algısı ölçeğinin geçerlilik ve güvenirlik çalışması. Bartın Üniversitesi Eğitim Fakültesi Dergisi, 3(1), 113-140. https://doi.org/10.14686/BUEFAD.201416210

Kenner, C., \& Kress, G. (2003). The multisemiotic resources of biliterate children. Journal of Early Childhood Literacy, 3(2), 179-202. https://doi.org/10.1177/14687984030032004

Krause, M. B. (2015). Facilitating a transdisciplinary approach in teacher education through multimodal literacy and cognitive neuroscience (Graduate Theses and Dissertations). College of Education University of South Florida, Florida.

Lankshear, C., \& McLaren, P. L. (1993). Critical literacy: Politics, praxis, and the post-modern. New York State University: New York Press.

Liu, J. (2013). Visual images interpretive strategies in multimodal texts. Journal of Language Teaching and Research, 4(6), 1259-1263. https://doi.org/10.4304/jltr.4.6.1259-1263

Loerts, T. S. (2013). Multimodal literacy learning opportunities in one grade six classroom: Possibilities and constraints (Doctoral Dissertation). The University of Western Ontario, London.

Özensoy, A. U. (2011). Eleştirel okumaya göre düzenlenmiş sosyal bilgiler dersinin eleştirel düşünme becerisine etkisi. Mersin Üniversitesi Eğitim Fakültesi Dergisi, 7(2), 13-25.

Pendleton, M. (2013). Through the Lens: Multimodal Science, Math, and Literacy Practices in an Elementary Classroom. Meridian, 16(1).

Rowsell, J., \& Walsh, M. (2011). Rethinking literacy education in new times: Multimodality, multiliteracies, \& new literacies. Brock Education Journal, 21(1), 53-62. https://doi.org/10.26522/brocked.v21i1.236

Sanders, J., \& Albers, P. (2010). Multimodal literacies: An introduction. In Albers, P. \& Sanders, J. (Eds.) Literacies, the arts, and multimodality (pp. 1-25). Urbana, Illinois: NCTE.

Serafini, F. (2010). Reading multimodal texts: Perceptual, structural and ideological perspectives. Children's Literature in Education, 41(2), 85-104. https://doi.org/10.1007/s10583-010-9100-5 
Sewell, W. C., \& Denton, S. (2011). Multimodal literacies in the secondary English classroom. English Journal, 100(5), 61-65.

Smith, A. M. (2014). Multimodal literacy in the English/Language arts classroom: Meeting standards and remaining relevant in the 21st Century (Master's Theses). Department of Education and Human Development of the College at Brockport, State University of New York, New York.

Tüzel, S. (2013). Çok katmanlı okuryazarlık öğretimine ilişkin Türkçe öğretmen adaylarının görüşlerinin incelenmesi. Eğitimde Kuram ve Uygulama, 9(2), 133-151.

Unsworth, L., \& Chan, E. (2009). Bridging multimodal literacies and national assessment programs in literacy. Australian Journal of Language and Literacy, 32(3), 245-257.

Walsh, M. (2009). Pedagogic potentials of multimodal literacy. In T.W. Leo \& H.R. Subramanian (Eds.), Handbook of research on new media literacy at the K-12 level: Issues and challenges (pp.32-47). US: Science Refference, Hershey. https://doi.org/10.4018/978-1-60566-120-9.ch003

Walsh, M. (2010). Multimodal literacy: What does it mean for classroom practice? Australian Journal of Language and Literacy, 33(3), 211-239.

Yıldırım, A., \& Şimşek, H., (2000). Sosyal bilimlerde nitel araştırma yöntemleri. Seçkin Yayıncılık. Ankara.

Yıldız, C. (Ed.) (2008). Kuramdan uygulamaya Türkçe ögretimi. Ankara: Pegem Akademi Yayıncılık.

\section{Copyrights}

Copyright for this article is retained by the author(s), with first publication rights granted to the journal.

This is an open-access article distributed under the terms and conditions of the Creative Commons Attribution license which permits unrestricted use, distribution, and reproduction in any medium, provided the original work is properly cited. 